International Journal of Agriculture, Environment and Bioresearch

Vol. 4, No. 06; 2019

ISSN: $2456-8643$

\title{
UNSUCCESSFUL CASSAVA BROWN STREAK DISEASE (CBSD)EVALUATION ATTEMPTS IN WESTERN DEMOCRATIC REPUBLIC OF CONGO AND IMPLICATIONS WITH CASSAVA ROOT NECROSIS DISEASE (CRND) ETIOLOGY
}

\author{
${ }^{1}$ Bakelana Zeyimo, ${ }^{2}$ Tata Hangy, ${ }^{1}$ Tevo Ndomateso, ${ }^{2}$ Mahungu NzolaMeso, ${ }^{3}$ Monde Godefroid,${ }^{4}$ Tshilenge \\ Kanana, ${ }^{4}$ Lema Ki Munseki and ${ }^{4}$ Kalonji Mbuyi \\ 1National Institute for Agricultural Research Studies (INERA), DRC \\ 2International Institute of Tropical Agriculture (IITA) \\ 3Institute Faculty of Agricultural Sciences / Yangambi, DRC \\ 4Agriculture Faculty - Kinshasa University / DRC
}

http://doi.org/10.35410/IJAEB.2019.4480

\begin{abstract}
Cassava brown streak disease (CBSD) is the second most important virus disease after Cassava mosaic disease (CMD), infecting cassava (ManihotesculetaCrantz) in Africa. The disease is caused by two distinct viruses, Cassava brown streak virus [2,3] and Ugandan Cassava brown streak virus (family, Potyviridae: genus, Ipomovirus). Transmission of CBSV from one plant to another is reported to occur through grafting CBSV-free with infected cuttings and subsequent dissemination by infected cuttings. The basic approach to control of CBSD is selecting planting material from symptomless mother plants. Graft inoculation is the most efficient and effective of the techniques for CBSD virus transmission and consequently cuttings are the most effective way of the disease spreading.

In early 2000s, cassava root necrosis similar to those of CBSD were reported in western provinces of Democratic Republic of Congo (RDC) (Kinshasa and Kongo Central) and up to date PCR diagnoses did not detect any causal agent related to the observed symptoms and the disease which was still referred as 'CBSD-like disease'.

Due to lack of molecular data and the similarity of root symptoms with CBSD, the existence of a virus has always been suspected to be the cause of CBSD-like propagation. Thus, 2 field experiments were proposed in order to verify the existence of a systematic transmission of a possible CBSD related virus, knowing that CBSD viruses are transmitted efficiently by cuttings.

The first trial focused on the field evaluation of CBSD - like infected and apparently uninfected planting materials, while the second trial involved the importation of tanzanian CBSD resistant genotypes for evaluation in INERA Mvuazi research center under CBSD-like infection conditions.
\end{abstract}

Results of the first trial did not show a systemic transmission of any CBSD-like pathogen while CBSD-resistant parents involved in the second trial all succumbed to CBSD-like disease. 
These results are the first experimental scientific evidence that the pathogen responsible for CBSD-like is not a virus and is not even related to CBSD viruses.

These results corroborate currently with recent molecular data obtained by NGS and which confirm the absence of any virus and suspect a possible transmission of CBSD-like by fungi and / or bacteria.

Therefore, CBSD-like has been named Cassava Root Necrosis Disease or CRND.

Keywords: CBSD - like, Virus transmission, CRND, Western DRC .

\section{INTRODUCTION}

Cassava brown streak disease (CBSD) is the second most important virus disease after Cassava mosaic disease (CMD), infecting cassava (ManihotesculetaCrantz) in Africa [1]. The disease is caused by two distinct viruses, Cassava brown streak virus [2,3] and Ugandan Cassava brown streak virus $[4,5]$ (family, Potyviridae: genus, Ipomovirus).

The disease was first reported from the East African coast in 1936 [6]. Disease symptoms of CBSD were documented by Nichols [7] and updated later by Hillocks and Jennings [8].

Transmission of CBSV from one plant to another is reported to occur through grafting CBSVfree with infected cuttings $[6,7,9,10]$ and subsequent dissemination by infected cuttings.

Storey (1936) [6] demonstrated that CBSV is graft-transmissible, and that cuttings from affected plants gave rise to plants showing characteristic foliar symptoms of the CBSD. Thus the disease is readily introduced into newly planted areas through the use of infected planting material [11].

Storey (1939) [10], reported that CBSD was widespread in coastal Tanzania and by 1950, the disease was endemic across coastal areas of East Africa from northeast Kenya, Tanzania to northern Mozambique at altitudes below 1000 masl[7]. The disease was reported in Uganda in 1945 and may have been introduced through infected cuttings sent from the Amani research station in Tanzania [7, 12]. Strict rouging of infected plants, replacement with non-infected planting material and quarantine appear to have prevented spread of CBSD in Uganda at this time [7].

The basic approach to control of CBSD is selecting planting material from symptomless mother plants.

Suspected transmission of CBSV by the whitefly vector B. tabaci[10] was confirmed in greenhouse and field experiments [13], although at rate ca $2 \%$. Previous attempts to transmit the virus by the aphid, MyzuspersicaeSulz (Hemiptera: Aphididae) and other aphid species failed [14].

Since vector transmission was demonstrated to be inefficient under controlled greenhouse and field conditions, non-vector mechanisms could contribute more widely to the spread of the virus. 
In the graft transmission experiments, 12-26 days were required to attain infection of all the test stock, suggesting that the method is the most efficient with respect to the rate of virus transmission. Shorter periods of ca. 4-weeks were required to attain $100 \%$ incidence in the infected rootstocks grafted to the virus- free scions compared to the five weeks in the virus-free rootstocks grafted to the infected scions.

None of the seedlings developed from seeds obtained from CBSD affected mother plants exhibited the disease symptoms. All plants tested negative for CBSV in RT-PCR even after repeated tests for more than six months. The CBSD symptoms were not observed in any of the seedlings even after repeated experimentation.

Cassava brown streak virus was not transmitted through seeds which support earlier findings [13]. The lack of CBSV transmission through seeds derived from infected mother plants suggest that the morphology of the reproductive organs of cassava does not allow entrance and survival of CBSV in the embryo.

Graft inoculation is the most efficient and effective of the techniques assessed because $100 \%$ transmission was attained.

The relatively shorter time required for the virus detection and symptoms expression when the CBSV-free scion was grafted onto an infected root stock suggests this technique to be the best for transmission studies.

The findings in this study are consistent with the CABRI [15] findings, that grafting is an effective way of transmitting virus strains that are not readily or not at all mechanically transmissible to susceptible host plants.

The following points highlight the eight chief methods used for the transmission of plant viruses. The methods are: 1. Seed Transmission of Virus 2. Transmission by Vegetative Propagation 3. Transmission by mechanical means 4 . Transmission by Cuscuta 5. Soil transmission 6. Insect transmission 7. transmission by fungi

8. Some soil Inhabiting Viruses have nematode vectors.

Transmission by vegetative propagation is one of the chief methods of transmission of virus diseases especially of potato, rose, sugarcane, raspberry, strawberry, turnips, bulb plants, fruit trees and many ornamentals.

The vegetative parts, the infected plants such as the tubers, bulbs, roots, offshoots, buds and scions which are used for propagation, will contain the virus present in the parent. The new plants raised by the above-mentioned vegetative methods are nearly always infected [16].

In early 2000s, cassava root necrosis (Figure 1) similar to those of CBSD were reported in western provinces of Democratic Republic of Congo (DRC) (Kinshasa and Kongo Central) by Mahungu et al. (2003) [17].and up to date PCR diagnoses did not detect any causal agent related to the observed symptoms and the disease which was still referred as 'CBSD-like disease'. 
Several attempts to identify the causative agent responsible for CBSD-like disease in western in DRC have been undertaken since 2004 using cassava leaf samples, including those from plants showing very severe symptoms, with no success to date [18]..

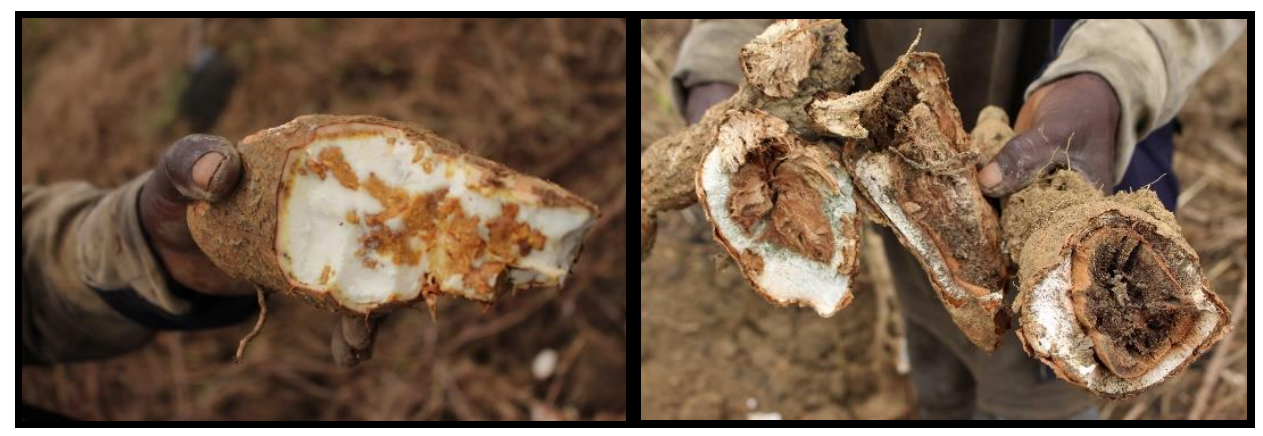

Figure 1: Severe cassava root necrosis due to CBSD-like at INERA- Mvuazi research center.

The impact of CBSD-like damages has been further amplified as most of the improved CMDresistant cassava cultivars deployed in DRC in recent years by INERA and IITA are sensitive to the causative agent of CRND. No source of resistance to root necrosis has been reported in DRC. It is therefore essential to identify a source of tolerance / natural resistance to root necrosis to create cultivars resistant to CBSD-like in DRC.

A number of sources of resistance / tolerance have been observed in Tanzania in the 1930s1940s, Amani's breeding program, originally aimed CMD resistance in Tanzania, but later incorporated CBSD, achieved several inter-specific crosses with a wild cassava parent, Manihotglaziovii .

In the breeding program, interspecific F1 hybrids were produced, crossed with each other and backcrossed with M. esculenta. Reasonable levels of resistance to both CBSD and CMD were generated.

When this breeding program was closed, genetic material lines were sent to Moore Estate, Nigeria, and were used by IITA, particularly to combat CMD.

Genetic material has also spread to farmers' fields in Tanzania. Tanzanian farmers have recently used this genetic material for resistance breeding against CBSD.

Three of the main varieties from this program are Namikonga, NDL06 / 132 and Kiroba. Nachinyaya is a fourth variety native to Tanzania, but is not thought to be from the Amani breeding program, which shows tolerance to CBSD. In addition, some tolerance was found in an interspecific variety created by CIAT, AR40-6.

Namikonga is therefore suspected of being an interspecific hybrid of the Amani program, which was later adopted by farming communities and given a local name. At present, Namikonga is 
still expressing resistance to CBSD and is being used as one of the best sources of CBSD resistance in conventional breeding programs ([19, 20, 21, 22, 23, 24].

The variety is cultivated to a limited extent by farmers in southeastern Tanzania, though its yield is low.

Whole genome sequencing analysis by Bredesonet et al. (2016) [25] revealed a parent-child relationship of Namikonga with a Nigerian variety TME117.

Namikonga shares an entire haplotype with TME117. One explanation for this is that prior to interspecific hybridization, many varieties of $M$. esculenta from different parts of the world, including West Africa, were evaluated for resistance to Amani virus [26].

It is suspected that TME 117 was one of these varieties as it was likely used as a parent in the Amani breeding program [27].

The evidence that Namikonga was derived from the Amani breeding program is that $14.4 \%$ of the genome of TheorAppl Genet (2017) 130: 2069-2090 207113 was M. glaziovii - M. esculenta hybrid type and contains an indicative introgression segment on chromosome 1 [25].

A diallel analysis conducted by Kulembeka et al. (2012) [28] found that resistance to CBSD in Namikonga was due to two or more genes with additive effects.

Since no evidence on the CBSD-like pathogen was found, field assessments on pathogen transmission and variety behavior vi-à-vis the disease were undertaken.

No source of resistance to CRND is known in the country till now. It is therefore essential to identify tolerant/ resistant accessions to mitigate this new observed cassava disease in western DRC.

While looking for sources of resistance to CBSD, some genotypes found to be tolerant or resistant to CBSD in Tanzania, namely; Namikonga, NDL06 / 132 and Kiroba, were introduced to DRC for evaluation, in order to create a source of CBSD resistance in locally bred materials. On the other hand, an experiment was set to assess whether the observed root necrosis could spread through cuttings as this happens with viral diseases. It is known that transmission of CBSV from one plant to another can be done through cuttings.

This article presents results of the evaluations made on the Tanzania introduced CBSD tolerant/resistant genotypes under CBSD-like conditions, and those of the transmission of CBSD-like pathogens through cuttings.

Activity 1.Transmission trial of a probable CBSD-like virus by cuttings.

Activity 2. Evaluation of tanzanian CBSD resistant varieties in CBSD-like infections conditions in western DR. Congo.

\section{Objectives}




\section{Activity 1.}

Assuming that the pathogen of CBSD-like is a different virus than CBSVs, it should be transmitted by grafting and consequently by cuttings.

Knowing that CBSD is very efficiently transmitted by grafting and consequently by cuttings, this study was initiated with the aim of exposing the CBSD-like apparently unaffected materials and the CBSD-like infected materials for field evaluation.

In order to observe if the infected material will reproduce symptoms by systemicity and show more symptoms compared to the material that will come from apparently healthy cuttings.

\section{Activity 2.}

This study aims to test the CBSD-resistant genotypes available in Tanzania (Namikonga, NDL06 / 132, Kiroba and AR40-6), vis-à-vis CBSD-like observed in western DR. Congo.

As a hypothesis, we assume that CBSD-resistant genotypes should be resistant to CBSD-like, so that the CBSD-like pathogen should be a CBSD related virus.

\section{MATERIALS AND METHODS}

\section{Activity 1.}

The first trial consisted of two treatments including; (a) apparently healthy cuttings from plants without root necrosis; and (b) cuttings from plants showing necrosis. Three different varieties of cassava selected according to their level of tolerance to CBSD-like, in terms of the damage caused by necrosis, in this case the variety (1) Obama seems sensitive, (2) RAV less sensitive (often presenting a level moderate damage), and (3) the Zizila variety with some level of tolerance. In this trial, the data collected focused on assessing the severity of root necrosis during harvests at 9, 12, 15 and 18 map.

For the assessment of root necrosis, sampled plants were uprooted. Roots were counted, and each root was then cut cross-sectionally five times at regular intervals along the length of the root.

Each root was cut transversely into five pieces (figure 2), and the cross sections were scored for necrotic symptoms on a scale of 1 to 5 of Hillocks and Thresh (2000) [11]., where $1=$ no necrosis, $2=\leq 5 \%$ necrotic; $3=6$ to $10 \%$ necrotic; $4=11$ to $25 \%$ necrotic and mild root constriction; and $5=>25 \%$ necrotic and severe root constriction. 


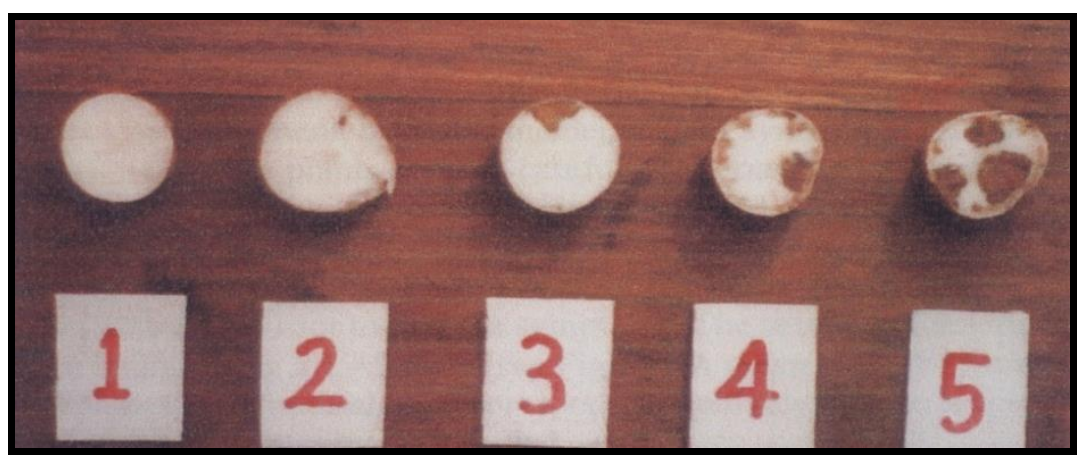

Figure 2: Root necrosis severity scores

The first trial was established according to the split plot experimental design with variety as the main factor and the cuttings phytosanitary state as a secondary factor, in three replications. The elementary plot was $5 \mathrm{~m} \times 10 \mathrm{~m}$.

While collecting cuttings, the precaution was taken that cuttings used were almost of the same age.

Whiteflies where not assessed due to the fact that Bemisiatabaci virus transmission rate in field is very low $(2 \%)[29]$.

The fact that a positive correlation have been found during surveys in western DR. Congo between CBSD-like severity and incidence [32], incidence data were not inferred from the severity data and then taken into account during the statistical analyses process..

\section{Activity 2.}

The second trial, whose main objective was the evaluation of CBSD resistant genotypes in western DR.Congo CBSD-like infection conditions.

Thus, in 2015, a batch of indexed cuttings (Figure 2) of these CBSD resistant materials were introduced in DR.Congo for evaluation at INERA Mvuazi research center. 


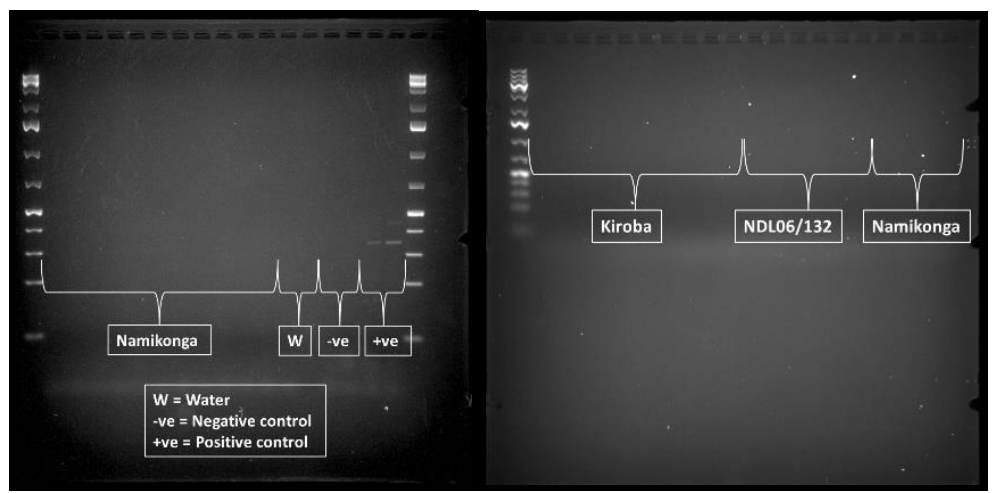

Figure 2 :Agarose gel from indexed plants (CMD free plants).

Introduced materials were planted using a completely randomized design and check varieties were included in the trial. These are Mputa, RAV and TME 419 genotypes. These genotypes were introduced in the trail due to their sensitivity to CBSD-like.

Root necrosis severity were assessed the same as in activity 1 at 12 and 18 months after plantation (map).

Table 1: Pedigree information of introduced CBSD resistant varieties

\begin{tabular}{|l|l|l|}
\hline \multicolumn{1}{|c|}{ Variety } & \multicolumn{1}{|c|}{ Pedigree } & \multicolumn{1}{|c|}{$\begin{array}{c}\text { Possible source of } \\
\text { CBSD } \\
\text { resistance/tolerance }\end{array}$} \\
\hline Namikonga & $\begin{array}{l}\text { Known as 'Kaleso' in Kenya. Third backcross from } \\
\text { inter-specific hybrid (46106/27) from M. glaziovii from } \\
\text { Amani breeding program. }\end{array}$ & M. glaziovii \\
\hline AR40-6 & $\begin{array}{l}\text { Bred by CIAT. Has 12.5\% from wild species } M . \\
\text { esculenta subsp. flavellifolia and 50\% from CMD } \\
\text { resistant variety C39. }\end{array}$ & Unknown \\
\hline Kiroba & $\begin{array}{l}\text { Landrace from Tanzania } \\
\text { NDL06/132 }\end{array}$ & $\begin{array}{l}\text { Breeding line selected at ARI Naliendele in southern } \\
\text { Tanzania. It is an S1 self of variety NAL 90/34 which } \\
\text { showed strong resistance to CBSD [5] and is half sib of } \\
\text { Kibaha. which has } M . \text { e. subsp. flabellifolia background. }\end{array}$ \\
\hline \multicolumn{2}{|c|}{} \\
\hline
\end{tabular}

Source: Kaweesi et al., 2014. 


\section{RESULTS AND DISCUSSION}

\section{Activity 1.}

Data from the assessment root necrosis maximum severity are recorded in Table 2 .

Table 2: Assessment of root necrosis maximum severity in Mvuazi.

\begin{tabular}{|l|c|c|c|c|}
\hline & 9 map & 12 map & 15 map & 18 map \\
\hline \multicolumn{5}{|c|}{ Type of plantingmaterials } \\
\hline $\begin{array}{l}\text { Apparently healthy and } \\
\text { without root necrosis }\end{array}$ & 1.41 & 1.79 & 2.18 & 2.09 \\
\hline Infectedwithrootnecrosis & 1.31 & 1.71 & 2.18 & 2.14 \\
\hline \multicolumn{5}{|c|}{ Genotypes } \\
\hline Zizila & 1.6 & 1.91 & 2.29 & 2.12 \\
\hline Obama & 1.27 & 1.70 & 2.52 & 2.21 \\
\hline RAV & 1.21 & 1.64 & 1.73 & 2.02 \\
\hline Mean & 1.37 & 1.75 & 2.16 & 2.08 \\
\hline Maximum & 2.33 & 3.75 & 4 & 5 \\
\hline CV (\%) & 27.54 & 33.41 & 35.62 & 26.78 \\
\hline LSD (.05) & $\mathrm{ns}$ & $\mathrm{ns}$ & $\mathrm{ns}$ & $\mathrm{ns}$ \\
\hline
\end{tabular}

Table 2 reveals that apparently healthy (uninfected) planting material and infectedplanting materials did not reveal any significant differences. This means otherwise that the health status of the planting materials did not have any effect on the manifestation of root symptoms. This totally contradicts the very efficient transmission of the CBSD virus by grafting and consequently by cuttings.

In other words, we can conclude that the pathogen (s) at the base ofCRND or CRND is not (are not) transmitted from cassava cuttings and are not CBSV or viral particles.

In comparison to previous results from the Plant Disease reporter, six to 8 months old cuttings from symptomless mother plants remained free of CBSD symptoms, and a pathogen could not be detected in transmission studies, a significant difference in the severity of root necrosis should be observed between infected and uninfected planting materials in the presence of any virus particle. 
Alicai et al. (2007) [30].found that CBSD in Uganda is maintained through the planting of infected cuttings.

These preliminary results are first experimental evidence of non-viral transmission of CBSDlike.

We can speculate at this stage that CRND pathogens could be fungi, bacteria or any else microorganisms not transmitted by grafting and cuttings and roguing of infected plants could not be recommended as a disease control strategy. And the whitefly Bemisiatabaci is certainly not involved in the spreading of CBSD-like.

\section{Activity 2}

Data on genotypes reactions against CBSD-like and the effect of the harvesting time are presented in table 2 and 3.

Table 2.Genotypes reactions to root necrosisin Mvuazi.

\begin{tabular}{|l|c|c|}
\hline Genotypes & Mean sev. & Max. sev. \\
\hline Mputa & $3.26 \mathrm{a}$ & $4.56 \mathrm{a}$ \\
\hline NDL 60/139 & $1.26 \mathrm{~b}$ & $2.52 \mathrm{c}$ \\
\hline TME 419 & $1.25 \mathrm{~b}$ & $3.25 \mathrm{~b}$ \\
\hline RAV & $1.12 \mathrm{~b}$ & $2.87 \mathrm{bc}$ \\
\hline Namikonga & $1 \mathrm{~b}$ & $3 \mathrm{bc}$ \\
\hline Kiroba & $1 \mathrm{~b}$ & $3.02 \mathrm{bc}$ \\
\hline Mean & 1.52 & 3.26 \\
\hline CV (\%) & 60.42 & 24.35 \\
\hline LSD (.05) & $* *$ & $* *$ \\
\hline
\end{tabular}

Table 2 shows that the genotype Mputa is the most susceptible to CBSD-like while all CBSD resistants genotypes presented CBSD-like symptoms at the same level with others DR.Congo susceptible genotypes. 
Table 3. Effects of harvesting time on root necrosis symptoms in Mvuazi.

\begin{tabular}{|l|c|c|}
\hline $\begin{array}{l}\text { Harvest } \\
\text { time } \\
\text { (map) }\end{array}$ & Meansev. & $\begin{array}{c}\text { Max. } \\
\text { sev. }\end{array}$ \\
\hline 12 & $1.37 \mathrm{a}$ & $2.97 \mathrm{~b}$ \\
\hline 18 & $1.52 \mathrm{a}$ & $3.47 \mathrm{a}$ \\
\hline Mean & 2.13 & 3.22 \\
\hline CV (\%) & 60.42 & 24.35 \\
\hline LSD (.05) & ns & $* *$ \\
\hline
\end{tabular}

Table 3 shows that the harvesting time was significantly different for the maximum severity parameter and not for the average severity.

After the ground evaluation of CBSD resistant parents (Namikonga, NDL06 / 132, Kiroba and AR40-6) at 12 map and 18 map in DR. Congo agro ecological conditions, all CBSD resistant varieties collapsed to CBSD-like.

This rejects the initial hypothesis that these CBSD-resistant genetic materials should withstand CBSD-like.

Namikonga collapsed in CBSD-like infection conditions in Mvuazi while Kawweesi et al. (2014) showed in Uganda that Namikonga had the highest proportion of plants with no root necrosis (83.3\%) in a field evaluation trials of selected varieties followed by NASE 1 and AR40-6 with $73.3 \%$ and $63.6 \%$ respectively. Namikonga and NASE 1 had a maximum root necrosis severity score of $2[21]$.

Namikonga, also known as Kaleso in Kenya, showed the highest general combining ability for resistance to CBSD $[28,31]$. This cultivar is now widely used by national breeding programs in East Africa.

This is indeed an experimental evidence obtained on the basis of a field trial that CBSD isa different disease to CBSD-like, given the sensitivity of CBSD-resistant materials to CBSD-like. 


\section{CONCLUSION AND RECOMMENDATIONS}

This experimental study has shown that CBSD-like and CBSD are different from the etiological and epidemiological points of view.

From the etiological point of view that they are not both caused by any virus and from an epidemiological point of view because sources of genetic resistance are differents.

These results therefore corroborate currently with different molecular data generated to date by PCR and NGS, that have shown that CBSD-like is another new disease different from CBSD, even root symptoms are similar just by coincidence.

For this reason, CBSD-like has been nominated Cassava Root Necrosis Disease or CRND.

\section{ACKNOWLEDGMENTS}

We thank IITA / SARD-SC project and Dr. Morag Ferguson from IITA / Kenya for the assistance in importing CBSD-resistant genotypes in DR.Congo.

We also thank IITA / DR. Congo for the financial resources allocated for trials management.

\section{REFERENCES}

1. JP. Legg andJM.Thresh, "Cassava virus disease in Africa". Plant virology in subSaharanAfrica.2003;517-552pp,2011. http://www.iita.org/info/virology/pdf_files/517552.pdf. Accessed August.

2. M.J. Adams, J.F. Antoniw and C.M. Fauquet, "Molecular criteria for genus and species discrimination within the family Potyviridae". Arch. Virol. ; 150: 459-479, 2015.

3. W.A. Monger, S. Seal, A.M. Isaac and G.D. Foster, "Molecular Characterization of cassava brown streak virus coat protein". Plant Pathol.; 50: 527-534, 2001.

4. D.R. Mbanzibwa, Y.P. Tian, A.K. Tugume, S.B. Mukasa, F. Tairo, S. Kyamanywa, A. Kulaya and P.T.J. Valkonen, "Genetically distinct strains of Cassava brown streak virus in the Lake Victoria Basin and the Indian Ocean Coastal areas of East Africa". Archives of Virology, 154: 353-359, 2019.

5. D.R. Mbanzibwa, Y.P. Tian, A.K. Tugume, B.L. Patil, J.S. Yadav, B. Bagewadi, M.M. Abarshi, T. Aliai, W. Changadeya, J. Mkumbira, M.B. Muli, S.B. Mukasa, F. Tairo, Y. Baguma, S. Kyamanywa, A. Kullaya, M.N. Maruthi, C.M. Fauquet and J.P.T. Valkonen, "Evolution of cassava brown streak-associated viruses". Journal of General Virology, 92:974-987, 2011.

6. H.H. Storey, "Virus Diseases of East African Plants VI. A progress report on studies of the disease of cassava". E. Afr. Agric. J., 12: 34-39, 1936. 
7. R.F.J. Nichols, "The brown streak disease of cassava: distribution, climatic effect and diagnostic symptoms”. E. Afr. Agric. J., 15: 154-160, 1950.

8. R.J. Hillocks and D.L. Jennings, "Cassava Brown Streak Disease: a review of present knowledge and research needs”. Intern. J. Pest Man., 49(3): 22523, 2003.

9. R.M. Lister, "Mechanical transmission of cassava brown streak virus". Nature, 1983: 1588$1589,1959$.

10. H.H. Storey, "Report of the Plant Pathologist". Annual Report from E. Afr. Agric. Res. Stat, 1939.

11. R.J. Hillocks, J.M. Thresh, "Cassava mosaic and cassava brown streak virus diseases in Africa: a comparative guide to symptoms and aetiologies", Roots 7, 1-8, 2000.

12. J.D. Jameson," Cassava mosaic disease in Uganda". East African Agriculture and Forestry Journal 30, 208 - 213, 1964.

13. M.N. Maruthi , R.J. Hillocks, K. Mtunda, M.D. Raya, M. Muhanna, H. Kiozia, A.R. Rekha , J. Colvin and J.M. Thresh, "Transmission of Cassava brown streak virus by Bemisiatabaci (Gennadius)”. J. Phytopath. , 153: 307-312, 2005.

14. A.M. Lennon, M.M. Aiton and B.D. Harrison, "Cassava Viruses from Africa". Scottish Crop Res. Inst. Annual Report for 1985., 168, 1986.

15. CABRI Grafting of virus infected plant material to healthy host plants. Laboratory procedures for plant cell viruses. The CABRI Consortium 1999-2003, 2004. http://www.cabri.org/guidelines/plant_virus/pcv202ap3.html. Accessed July, 2010.

16. http://www.biologydiscussion.com/viruses/transmission-of-plant-viruses-8-methodsvirology/64193

17. N.M. Mahungu, M. Bidiaka, H. Tata, S. Lukombo and S. N'luta, "Cassava brown streak disease-like symptoms in Democratic Republic of Congo". ROOTS, 8, 8-9, 2003.

18. Z. Bakelana, E. Magembe, L. Boykin, M. Macharia, N. Mahungu, T. Hangy, D. Lutete, G. Monde, J. Harvey, J. Ndunguru, C. Kayuki, J. Pita, K.M. Lema, K. Tshilenge, "Attempts to Identify Cassava Brown Streak Virus in Western Democratic Republic of Congo" , Journal of Agriculture Science, Vol. 11. N², 2019.

19. D.L. Jennings, "Further studies in breeding cassava for virus resistance." E. Afr. Agric. J., 22: 213-219, 1957.

20. E.E. Kanju, G. Mkamilo, V. Mgoo, M.E. Ferguson, "Statistical evi- dence linking the zigzag stem habit with tolerance to cassava brown streak disease", Roots 12:4-6, 2010.

21. T. Kaweesi, R. Kawuki, V. Kyaligonza, G. Tusiime, M.E. Ferguson, "Field evaluation of selected cassava genotypes for cassava brown streak disease based on symptom expression and virus load". Virol J 11:1-14, 2014. 
22. M.N. Maruthi, S. Bouvaine, H.A. Tufan, I.U. Mohammed, R.J. Hillocks, "Transcriptional response of virus-infected cassava and identification of putative sources of resistance for cassava brown streak disease". PLoS One 9:e96642, 2014.

23. A. Pariyo, P. Tukamuhabwa, Y. Baguma, R.S. Kawuki, T. Alicai, P. Gib- son, E. Kanju, B.W. Wanjala, J. Harvey, I. Nzuki, I.Y. Rabbi, M. Ferguson, "Simple sequence repeats (SSR) diver- sity of cassava in South, East and Central Africa in relation to resistance to cassava brown streak disease". Afr J Biotech 12:4453-4464, 2013.

24. G.M. Rwegasira, C.M. Rey, "Response of selected cassava varie- ties to the incidence and severity of cassava brown streak disease in Tanzania".J AgricSci 4, 237-245, 2012.

25. J.V. Bredeson, J.B. Lyons, S.E. Prochnik, G.A. Wu, C.M. Ha, E. Edsinger- Gonzales, J. Grimwood, J. Schmutz, I.Y. Rabbi, C. Egesi, P. Nau- luvula, V. Lebot, J. Ndunguru, G. Mkamilo, R.S. Bart, T.L. Setter, R.M. Gleadow, P. Kulakow, M.E. Ferguson, S. Rounsley, D.S. Rokhsar, "Sequencing wild and cultivated cassava and related species reveals extensive interspecific hybridization and genetic diversity". Nat Biotechnol 34:562-570, 2016.

26. R. Nichols, "Breeding cassava for virus resistance". East AfrAgric J., 12:184-194, 1947.

27. D.L. Jennings, "Further studies in breeding cassava for virus resistance". East AfrAgric J 22:213-219, 2015.

28. H. Kulembeka, M. Ferguson, L. Herselman, E. Kanju, G. Mkamilo, E. Masumba, M. Fregene, M. Labuschagne, "Diallelanaly- sis of field resistance to brown streak disease in cassava (ManihotesculentaCrantz) landraces from Tanzania”. Euphytica 187:277-288, 2012.

29. M.N. Maruthi, R.J. Hillocks, K. Mtunda, M.D. Raya, M. Muhanna, H. Kiozia, A.R. Rekha, J. Colvin and J.M. Thresh, "Transmission of Cassava brown streak virus by Bemisiatabaci (Gennadius)". J. Phytopath., 153: 307-312, 2005.

30. T. Alicai, C.A. Omongo, M.N. Maruthi, R.J. Hillocks, Y. Baguma, R. Kawuki, A. Bua, G.W. Otim-Nape and J. Colvin, "Re-emergence of Cassava Brown Streak Disease in Uganda". Plant Dis., 91(1): 24-29, 2007.

31. T. L. Munga, "Breeding for Cassava Brown streak resistance in Coastal Kenya". Republic of South Africa.

32. Z. Bakelana, J. Pita, K. Mwangu, N. Tevo, K. Mayanza, M. Betezi, N. Tuwizana, T. Mukendi, N. Tshiamala, N. M. Mahungu , G. Monde, K.M. Lema, K. Tshilenge and M. Kalonji, "Assessing the Severity and the Incidence of Cassava Root Necrosis Disease (CRND) in Western Democratic Republic of Congo, 2019. Unpublished. 